\title{
DÜBLIN
}

Technological University Dublin

ARROW@TU Dublin

\section{Cutinase from Amycolatopsis mediterannei: marked activation and stabilisation in Deep Eutectic Solvents}

\author{
Yeq Tan \\ Technological University Dublin, Yeqi.Tan@TUDublin.ie \\ Gemma K. Kinsella \\ Technological University Dublin, gemma.kinsella@tudublin.ie \\ Gary T. Henehan \\ Technological University Dublin, gary.henehan@tudublin.ie
}

See next page for additional authors

Follow this and additional works at: https://arrow.tudublin.ie/schfsehart

Part of the Life Sciences Commons

\section{Recommended Citation}

Tan, Y., Henehan, G. T., Kinsella, G. K., \& Ryan, B. J. (2021). Cutinase from Amycolatopsis mediterannei: Marked activation and stabilisation in Deep Eutectic Solvents. Bioresource Technology Reports, 16, 100882. DOI: 10.1016/j.biteb.2021.100882

This Article is brought to you for free and open access by the School of Food Science and Environmental Health at ARROW@TU Dublin. It has been accepted for inclusion in Articles by an authorized administrator of ARROW@TU

Dublin. For more information, please contact

arrow.admin@tudublin.ie, aisling.coyne@tudublin.ie, gerard.connolly@tudublin.ie.

Funder: TU Dublin

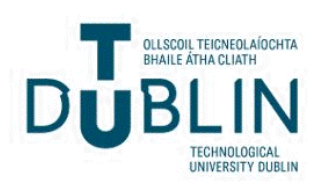


Authors

Yeq Tan, Gemma K. Kinsella, Gary T. Henehan, and Barry J. Ryan

This article is available at ARROW@TU Dublin: https://arrow.tudublin.ie/schfsehart/460 
1 Cutinase from Amycolatopsis mediterannei: marked activation and stabilisation in Deep

2 Eutectic Solvents

3

4

5 Grangegorman, Dublin 7, D07 H6K8, Ireland

6 * gemma.kinsella@,TUDublin.ie; Ph: 00353-1-220 5663 7 ORCID: 0000-0002-6329-5841
9

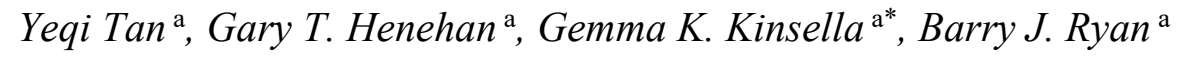

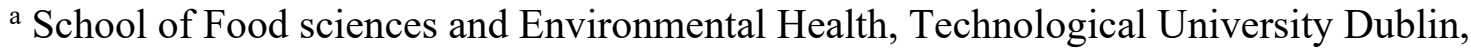

8

\section{Abstract}

Amycolatopsis mediterranei cutinase (AmCut) has potential biocatalytic applications in plastics degradation and ester synthesis. Deep Eutectic Solvents (DES) are next generation biodegradable solvents for biocatalysis. However, the behaviour of cutinase enzymes in DES is little studied. Herein, we examine the effect of selected DES, and their components, on AmCut activity and stability. Low amounts (10\% v/v) of DES (choline chloride:glycerol; 1:1 mole ratio) caused striking activation of AmCut (over 2-fold). Further examination showed that the choline chloride component of DES caused the observed activation. This is the first report of activation of a cutinase by a small molecule. At higher concentrations $(50 \% \mathrm{v} / \mathrm{v})$, DES composed of a choline chloride with glycerol as hydrogen bond donor dramatically increased the thermostability of AmCut - the enzyme lost no activity after incubation at $50^{\circ} \mathrm{C}$ for 2 hours. The biotechnological utility and physiological relevance of choline chloride activation and stabilisation is discussed.

Keywords: Activation, Amycolatopsis mediterannei, Choline, Cutinase, Deep Eutectic Solvents, Stability. 
27 Cutinases and lipases are related $\alpha / \beta$ hydrolases that differ in their substrate specificity and structural features. A key difference between these enzymes is the presence of a lid structure covering the active site of lipases but not cutinases. In the case of lipases, the lid opens at a lipid/water interface to provide for enhanced substrate access and increased activity - a phenomenon known as interfacial activation. This type of conformational change is not a feature of classical cutinases and they do not exhibit interfacial activation. Indeed, the lack of a lid structure and the lack of interfacial activation are distinguishing characteristics of cutinases (see Nikolaivits et al., 2018: Chen et al., 2013; Nyyssölä, 2015). One exception is the report of a novel class of cutinase with a lid-covered active site which displays interfacial activation in the manner of a "true" lipase (Roussel et al., 2014).

Amycolatopsis mediterranei secretes an extracellular lipase-like enzyme (AmCut) that was shown to catalyse the synthesis of flavour esters (Dheeman et al., 2011). Structural studies revealed that AmCut had specificity for medium chain acyl moieties and lacked the lid structure found in "true" lipases. Therefore, it was classified as a cutinase (Tan et al., 2021). The open, surface-exposed, active site of cutinases has meant that they are often more appropriate than lipases for applications such as textile bioscouring, biomass processing, polyester hydrolysis, certain enantioselective synthesis reactions and plastics degradation (Martínez and Maicas, 2021; Su et al., 2018; Nyyssölä, 2015; Chen et al., 2013;). Recent studies in this laboratory showed that AmCut was capable of depolymerising certain plastics; polycaprolactone and polybutylene succinate but not polylactide, under mild conditions (Tan et al., 2021). The potential to use enzymes in plastics degradation is important since many of the existing and the emerging generation of biodegradable bioplastics are slow to degrade in 
al., 2021; Kim et al., 2017). The activity and thermostability of AmCut is critical for these types of application.

Deep Eutectic Solvents (DES) are an emerging green chemistry medium for biocatalytic reactions. They are non-toxic, biodegradable, environmentally benign solvents. They are increasingly being explored as an alternative to commonly used toxic organic solvents. The effect of DES on enzyme activity is complex. They can activate or inhibit enzymes depending on their composition and concentration (Uhoraningoga et al., 2021; Mannu et al., 2021; Nascimento et al., 2019; Domínguez de María et al., 2018;). Many “true” lipases are activated in DES and the degree of activation reported varies widely, typically in the range $105 \%$ to $165 \%$ (but in one case $355 \%$ ), depending on the enzyme and the nature of the DES employed (Elgharbawy et al., 2018; Kim et al., 2016).

In general, increasing the stability and activity of enzymes used in biocatalytic processes is desirable. Due to their commercial importance, immobilisation, enzyme entrapment and site directed mutagenesis have all been used to improve cutinase stability and activity (Martínez and Maicas, 2021; Chen et al., 2013; Nyyssölä, 2015). The activation of lipases in DES is well known and has been explained by some researchers as being due to enhanced mobility of the lid region (Shehata et al., 2020) and in other cases to the direct participation of DES components in catalysis via H-bonding with active site moieties (Nian et al., 2019). There is, however, a lack of data on the behaviour of cutinases, and indeed many other biotechnologically significant enzymes, in DES. In this study, the activity of a wildtype, recombinant, AmCut was examined in the presence of three different cholinium DES preparations. Choline chloride was used as hydrogen bond acceptor (HBA) and glycerol, urea and glucose were the hydrogen bond donors (HBD). A 200\% activation of AmCut in the presence of $10 \% \mathrm{v} / \mathrm{v}$ cholinium DES based on glycerol as HBD was observed and attributed to the presence of choline chloride. DES was also responsible for the stabilisation of AmCut. 
Thus, AmCut lost no activity after incubation at $50^{\circ} \mathrm{C}$ for 2 hours in $50 \%$ DES (choline chloride: glycerol; 1:1 mole ratio). The activity enhancement and stabilisation seen in the presence of DES will pave the way for AmCut, and perhaps other cutinases, to be used in the presence of this DES in a range of biocatalytic processes. Moreover, AmCut will be a useful model for exploring the mechanism of DES/choline chloride activation since the influence of a lid structure can be discounted.

\section{Material and Methods}

All chemicals were obtained from Sigma Aldrich.

2.1 Enzyme purification: The isolation of recombinant Amycolatopsis mediterannei cutinase was carried out as previously described (Tan et al., 2021).

Standard activity assay: Lipase activity was assayed as described previously (Dheeman, et al., 2011) using $1.0 \mathrm{mM}$ paranitrophenol palmitate $(p-\mathrm{NPP})$ as the substrate at $37^{\circ} \mathrm{C}$ in $50 \mathrm{mM}$ phosphate buffer $\mathrm{pH}$ 7.5. Briefly, assays were carried out in a Greiner CELLSTAR ${ }^{\circledR} 96$ well plate UV spectrophotometer. Each well contained $230 \mu 1$ final substrate solution and $20 \mu 1$ lipase solution. Upon mixing, the plate was incubated for $10 \mathrm{mins}$ at $37^{\circ} \mathrm{C}$. The absorbance of the reaction at $400 \mathrm{~nm}$ was used to monitor the release of $p$-nitrophenol. All experiments were performed in triplicate.

2.2 DES synthesis: The synthesis of $\mathrm{ChCl}$ based DES was carried out according to the procedure as outlined in Tan et al., 2021. Briefly, the choline chloride salt and hydrogen bond donors were mixed at the specific molar ratio in a beaker and heated to $100^{\circ} \mathrm{C}$ in a water bath with stirring until a clear, homogenous liquid was formed. After cooling, the synthesised DES were stored in a desiccator until required for use.

2.3 Temperature stability: Temperature stability was examined by adding DES to the buffer component of the assay mixture. An initial activity measurement of AmCut in the presence of 

the DES was taken $(t=0 \mathrm{~h})$. At the end of the incubation at $50^{\circ} \mathrm{C}$ the activity was again measured $(\mathrm{t}=2 \mathrm{~h})$. The activity at $\mathrm{t}=2 \mathrm{~h}$ was expressed as a percentage of activity at $\mathrm{t}=0 \mathrm{~h}$. 2.4 Data Analysis: All experiments were carried out as independent triplicates and the differences between the mean of the reference and the samples were analysed using onetailed t-test (paired two samples for mean). Samples with a statistically significant difference to the reference were marked with asterisks $(* * \mathrm{p}<0.05)$.

107

\section{Results and Discussion}

The hydrogen bond donors employed were an alcohol (glycerol; ChCl:Gly), an amide (urea; $\mathrm{ChCl:U}$ ), and a sugar (glucose; ChCl:Glu). The DES synthesised with glucose was highly viscous and it was necessary to add some water to the solvent for ease of handling. This effectively diluted the DES and it was used in this dilute form. The composition of the DES used, and the mole ratio of their components, is shown in Tablel. 
117 Figure 1 shows the activity of AmCut in the presence of a low amount $(10 \% \mathrm{v} / \mathrm{v})$ of the three DES mixtures examined: ChCl:Gly, $\mathrm{ChCl}: \mathrm{U}$ and $\mathrm{ChCl}: \mathrm{Glu}$.

Figure 1 here

It was apparent that the presence of the DES containing choline chloride and glycerol had a remarkable activating effect on this enzyme while that with glucose also had a significant but lesser effect probably due to the presence of higher amounts of water in the ChCl:Glu mixture (due to its dilution for ease of handling, see Table 1). The DES composed of choline chloride and glycerol doubled the AmCut activity. While lipases have been shown to be activated by DES this, to the best of our knowledge, is the first time such activation has been reported for a cutinase. 
The concentration of $1.0 \mathrm{M}$ choline chloride corresponds to a solution of $14 \% \mathrm{w} / \mathrm{v}$. To explore this phenomenon further the concentration dependence of choline chloride activation was examined (Figure 3).

\section{Figure 3 here}

Clearly, choline chloride was responsible for considerable activation which reached a maximum at levels between 0.5 and $1.5 \mathrm{M}(7$ and $21 \%)$.

Activation by choline chloride appeared to be a saturable process and the activity increase was seen to level out at concentrations between 0.5 and $1.0 \mathrm{M}$ and reach almost 2.5 times the activity of the control. This is a high level of activation for enzymes of this kind. The activation of lipases is a well-known phenomenon particularly at oil/water interfaces and is due to the opening of a lid domain covering the active site. In the case of AmCut, this is not a contributing factor in its activation since it does not possess an active site lid. A recent study of activation of Candida antartica B lipase (CALB) in DES (it showed an activation of $115 \%$ ) concluded that hydrogen bonding with active site bound substrate was the factor contributing to activation (Nian et al., 2019). The latter model therefore, is one possible explanation for the activation seen with AmCut.

AmCut shares a high level of sequence similarity with two known plastic degrading enzymes: a PETase from Ideonella sakaiensis (67\% similarity) and Thermobifida fusca (TfCut2) cutinase (77\% similarity; see Tan et al., 2021). Given the similarity between these enzymes and AmCut it is possible that choline chloride activation is a common feature of these related cutinases. 


\subsection{Stabilisation of AmCut by DES}

The effect of DES on the stability of AmCut was also studied at $50^{\circ} \mathrm{C}$ over a period of two hours. In this experiment, AmCut was added to a solution containing the appropriate DES and its activity was measured. The enzyme was assayed again after 2 hours at $50^{\circ} \mathrm{C}$. AmCut in buffer, without DES, was shown to lose activity under such conditions showing a reduction to roughly $20 \%$ of initial activity (see Figure 4). Remarkably, the presence of DES significantly stabilised the enzyme and the stabilisation was greater at higher levels (50\%) DES.

\section{5}

6

(1)

8

This degree of stabilisation is significant. In the absence of DES, approximately $80 \%$ of activity was lost following 2 hours incubation at $50^{\circ} \mathrm{C}$. The presence of $10 \% \mathrm{v} / \mathrm{v} \mathrm{ChCl:Gly}$ reduces this loss in activity to approximately $60 \%$ of its initial activity. When the level of DES was increased to $50 \%(\mathrm{v} / \mathrm{v})$, no loss of activity was seen after 2 hours incubation at $50^{\circ} \mathrm{C}$. Similar results were observed for $\mathrm{ChCl}$ :Glu; however, notably, $\mathrm{ChCl}: \mathrm{U}$ did not have a stabilising effect on AmCut under these conditions.

The individual components of those DES that provided the stabilisation were subsequently examined for their stabilising effects on AmCut when incubated at $50^{\circ} \mathrm{C}$ for 2 hours (Figure $5)$.

\section{Figure 5 here}

It was clear that choline chloride (at $21 \% \mathrm{v} / \mathrm{v}$ or $1.5 \mathrm{M}$ ) had a pronounced effect on stabilisation of AmCut. These findings show the activation and stabilisation of AmCut in 
DES due to the presence of the choline chloride moiety. To the best of our knowledge this is the first example where stabilisation by DES has been ascribed to choline chloride.

This is a preliminary study, confined to a single cutinase, and is limited in that extent. Nevertheless, it is of considerable interest that a cutinase can achieve an activated and stabilised state in Deep Eutectic Solvents due to the presence of choline chloride. Given the importance of such enzymes in a wide range of processing and chemoenzymatic processes this study shows that the inclusion of DES is a useful consideration where cutinase thermal stabilisation/activation is required.

\subsection{General Discussion}

The behaviour of enzymes in DES is complex with some enzymes being activated while others are inhibited depending, not only on the enzyme, but also on the DES employed (Uhoraningoga et al., 2021; Mannu et al., 2021; Nascimento et al., 2019). Several studies have shown that the DES nanostructure is retained when water is present as a co-solvent at levels up to $20 \%$ v/v. From $20 \%$ v/v up to $50 \%$ v/v, DES becomes a co-solvent and is present as clusters dispersed in an aqueous phase. Above $50 \% \mathrm{v} / \mathrm{v}$ water, the solution changes into an aqueous electrolyte-like mixture of DES components (see e.g., Domínguez de María et al., 2019). In this work, activation was observed at $10 \%$ (v/v) DES. At this level, the individual DES components are likely to be fully dissociated and, therefore, their components must be causing the observed activation. This was confirmed by the observation that choline chloride caused the observed activation when used alone.

The inset of Figure 2 shows a direct comparison of choline chloride alone versus choline chloride as part of a DES at the same inclusion level (w/v). The hydrogen bond donor (glycerol) clearly serves to reduce overall AmCut activity. It is possible to make some observations from this data. The activation effect of the $\mathrm{ChCl}$ : $\mathrm{Gly}$ versus $\mathrm{ChCl}$ alone depends 
on the hydrogen bond donor. From Figures 1 and 2, Urea is shown to be inhibitory. Glycerol is also somewhat inhibitory (Figure 2) and therefore, a DES with glucose as hydrogen bond donor would seem to be most appropriate for activation (albeit viscous and difficult to handle). There is also the question of inclusion level. At low \% DES, the activation effect predominates but this is clearly a saturable process (see Figure 3). It is expected that inhibition by glycerol might increase at higher levels of DES (say $>50 \%$ ) while activation by choline chloride will reach a maximum. The net effect will be inhibitory at high DES inclusion levels. This data suggests that a DES of choline chloride and glucose might give the best overall performance (since glucose has no inhibitory effect) but clearly, there are a number of factors to consider. The choice of a DES will depend on factors such as enzyme stability, substrate solubility, inhibition by DES components, competing hydrolysis reactions and, of course, cost. Further studies are required to tease out these complex interactions.

It is difficult to explain the effect of choline chloride on both activity and stability and they may be separate processes. One possible explanation is that the binding of choline chloride triggers an AmCut conformational change to a form that is both higher in activity and stability. This could relate to its role in vivo where such a conformational change could enhance surface adhesion and binding to choline containing lipids, for example. Researchers have shown that the surface adhesion of cutinases greatly enhances their efficiency (Ribitsch and Guebitz, 2020). Further work is needed to understand this feature further.

The use of DES as an aid to tissue disruption when extracting bioactive compounds from natural sources is growing rapidly (Ivanović et al., 2020). This study shows that cutinase may be usefully employed as an adjunct to DES for this purpose to aid in the breakdown of biomass. 
241 Given the considerable efforts undertaken to improve the activity and stability of cutinases

242 via mutagenesis and immobilisation for specific applications, it will be of some interest that

243 enhanced activity and stability may also be achieved by judicious choice of cosolvent. The

244 use of choline chloride in conjunction with other means of stabilising cutinases such as

245 glycosylation (Shirke et al., 2016) will extend the operating range of cutinases into new areas

246 of application.

247

\section{Conclusions}

249

250

251

252

253

254

255

256

257

258

259

260

261

262

263

264

265

AmCut is activated and stabilised in certain Deep Eutectic Solvents, although not in all, due to the action of choline chloride. This activation will be useful in extending the operating range of this enzyme in biocatalytic applications. AmCut will serve as a useful model enzyme to examine the activation process. Finally, this study paves the way for the use of activated, stabilised AmCut in DES for biocatalysis and polyester degradation. Future studies will explore AmCut activation and its application in detail.

\section{Acknowledgement}

This research was funded by Fiosraigh Scholarship (PB04049) granted by Technological University Dublin.

\section{Author Contributions:}

YT; GTH; GKK; BJR: Conceptualization, Methodology. YT: Investigation. YT: Data curation, Writing. GTH; GKK; BJR: Supervision. GTH; GKK; BJR: Writing- Reviewing and Editing. 


\section{References}

267 Chen, S, Su, L., Chen, J., Wu, J. (2013). Cutinase: characteristics, preparation, and application. Biotechnol. Adv., 31(8), 1754-67.

Dheeman, D.S., Henehan, G.T., Frías J.M. (2011). Purification and properties of Amycolatopsis mediterranei DSM 43304 lipase and its potential in flavour ester synthesis. Bioresour. Technol., 102(3), 3373-9.

Domínguez de María, P., Guajardo, N., Kara, S. (2019). Enzyme catalysis: In DES, with DES, and in the presence of DES. In Deep Eutectic Solvents: Synthesis, Properties and Applications; Ramón, D.J., Guillena, G., Eds.; Wiley-VCH: Weinheim, Germany, pp. 257-272.

Elgharbawy, A.A., Hayyan, A., Hayyan, M., Rashid, S.N., Nor, M.R.M., Zulkifli, M.Y., ... Mirghani, M.E.S. (2018). Shedding Light on Lipase Stability in Natural Deep Eutectic Solvents. Chem. Biochem. Eng. Quart., 32 (3), 359-370.

Ivanović, M., Islamčević Razboršek, M., Kolar, M. (2020). Innovative Extraction Techniques Using Deep Eutectic Solvents and Analytical Methods for the Isolation and Characterization of Natural Bioactive Compounds from Plant Material. Plants, $9(11), 1428$.

Kim, M.Y., Kim, C., Moon, J., Heo, J., Jung, S.P., Kim, J.R. (2017). Polymer Film-Based Screening and Isolation of Polylactic Acid (PLA)-Degrading Microorganisms. $J$. Microbiol. Biotechnol. 27(2), 342-349.

Kim, S.H. , Park, S. , Yu, H. , Kim, J.H., Yang, Y.H. (2016). Effect of deep eutectic solvent mixtures on lipase activity and stability, J. Mol. Catal. B Enzym., 128, 65-72

Mannu, A., Blangetti, M., Baldino, S., Prandi, C. (2021). Promising Technological and Industrial Applications of Deep Eutectic Systems. Materials, 14(10), 2494. 
Martínez, A.; Maicas, S. (2021). Cutinases: Characteristics and Insights in Industrial Production. Catalysts, 11, 1194.

Monhemi, H., Housaindokht, M.R., Moosavi-Movahedi, A.A., Bozorgmehr, M.R. (2014). How a protein can remain stable in a solvent with high content of urea: insights from molecular dynamics simulation of Candida antarctica lipase $B$ in urea : choline chloride deep eutectic solvent. Phys Chem Chem Phys., 16(28):14882-93.

Nascimento, P.A.M., Picheli, F.P., Lopes, A.M., Pereira, J.F.B., Santos-Ebinuma, V.C. (2019). Effects of cholinium-based ionic liquids on Aspergillus niger lipase: Stabilizers or inhibitors. Biotechnol. Prog., 35(5), e2838.

Nian, B., Cao, C., Liu, Y. (2019). Activation and stabilization of Candida antarctica lipase B in choline chloride-glycerol-water binary system via tailoring the hydrogen-bonding interaction. Int. J. Biol. Macromol. 1(136), 1086-1095.

Nikolaivits, E., Kanelli, M., Dimarogona, M., Topakas, E. (2018). A middle-aged enzyme still in its prime: Recent advances in the field of cutinases. Catalysts, 8, 612 .

Nikolaivits, E., Pantelic, B., Azeem, M., Taxeidis, G., Babu, R., Topakas, E., Brennan Fournet, M., Nikodinovic-Runic, J., (2021). Progressing Plastics Circularity: A Review of Mechano-Biocatalytic Approaches for Waste Plastic (Re)valorization. Front. Bioeng. Biotechnol., 9, 696040.

Nyyssölä, A. (2015). Which properties of cutinases are important for applications? Appl. Microbiol. Biotechnol., 99 (12), 4931-42.

Ribitsch, D., Guebitz, G.M. (2020). Tuning of adsorption of enzymes to polymer. Methods Enzymol. 648, 293-315.

Roussel A, Amara S, Nyyssölä A, Mateos-Diaz E, Blangy S, Kontkanen H, WesterholmParvinen A, Carrière F, Cambillau C. A (2014). Cutinase from Trichoderma reesei 
with a lid-covered active site and kinetic properties of true lipases. $J$ Mol Biol. $426(22): 3757-3772$.

Shehata, M., Unlu, A., Sezerman, U., Timucin, E. (2020). Lipase and Water in a Deep

Eutectic Solvent: Molecular Dynamics and Experimental Studies of the Effects of Water-In-Deep Eutectic Solvents on Lipase Stability. J. Phys. Chem. 124(40), 88018810.

Shirke AN, Su A, Jones JA, Butterfoss GL, Koffas MA, Kim JR, Gross RA. (2017). Comparative thermal inactivation analysis of Aspergillus oryzae and Thiellavia terrestris cutinase: Role of glycosylation. Biotechnol Bioeng. 114(1):63-73

Su, An., Tyrikos-Ergas, T, Shirke, AN, Zou, Y, Dooley, AL, Pavlidis, IV, Gross, RA. (2018). Revealing Cutinases' Capabilities as Enantioselective Catalysts $A C S$ Catalysis 8 (9), 7944-7951.

Tan, Y., Henehan, G.T., Kinsella, G.K., Ryan, B.J. (2021). An extracellular lipase from Amycolatopsis mediterannei is a cutinase with plastic degrading activity. Comput. Struct. Biotechnol. J., 20, 869-879.

Uhoraningoga, A, Kinsella, G.K,, Henehan, G.T., Ryan, B.J., (2021). $\beta$-glucosidase from Streptomyces griseus: Ester hydrolysis and alkyl glucoside synthesis in the presence of Deep Eutectic Solvents, Current Research in Green and Sustainable Chemistry, 4, 100129.

\section{Figure Captions:}

Figure 1: Effect of DES on the activity of AmCut. The enzyme was assayed at $37^{\circ} \mathrm{C}$ in $50 \mathrm{mM}$ phosphate buffer pH7.5. Relative activity (\%) was determined by setting the activity of AmCut in buffer as the $100 \%$ reference. All percentages refer to v/v. Note: ChClGlu was highly viscous and diluted with $27 \% \mathrm{v} / \mathrm{v}$ water to allow for ease of handling (see Table 1). All percentages refer to $\mathrm{v} / \mathrm{v}$. 
Figure 2: Effect of DES components on AmCut activity. AmCut was assayed at $37^{\circ} \mathrm{C}$ in $50 \mathrm{mM}$

340 phosphate buffer $\mathrm{pH}$ 7.5. Relative activity (\%) was determined by setting the activity of AmCut in

341 buffer as the $100 \%$ reference. The inset shows a direct comparison of $\mathrm{ChCl}$ as a component of $\mathrm{DES}$

342 (ChCl:Gly) at a level of $6 \%$ versus $\mathrm{ChCl}$ alone at $6 \%(\mathrm{w} / \mathrm{v})$.

343 Figure 3: Effect of Choline Chloride $(\mathrm{ChCl})$ concentration on the activity of AmCut. The enzyme

344 was assayed using the standard $p \mathrm{NPP}$ assay in the presence of 0 to $1.5 \mathrm{M}$ of choline chloride at $37^{0} \mathrm{C}$ in

$34550 \mathrm{mM}$ sodium phosphate buffer, $\mathrm{pH}$ 7.5. Relative activity was determined using the activity of

346 AmCut in buffer as the $100 \%$ reference.

347 Figure 4: Effect of DESs on the stability of AmCut at $50^{\circ} \mathrm{C}$. The enzyme was incubated in phosphate 348 buffer $\mathrm{pH} 7.5$ containing appropriate DESs at $50^{\circ} \mathrm{C}$ for $2 \mathrm{hrs}$ and then assayed using the standard 349 assay at $37^{\circ} \mathrm{C}$ in $\mathrm{pH} 7.5$. The relative activity was calculated using the percentage of initial activity $(\mathrm{t}=$ $3500 \mathrm{~h})$ of the sample and after the incubation $(\mathrm{t}=2 \mathrm{~h})$. All percentages refer to $\mathrm{v} / \mathrm{v}$.

351 Figure 5: Effect of individual component of DES on AmCut activity at $50^{\circ} \mathrm{C}$. The enzyme was incubated in phosphate buffer (pH7.5) in the presence of DES components for $2 \mathrm{hrs}$ and assayed using

353 the standard assay at $37^{\circ} \mathrm{C}$. Relative activity was the percentage of initial activity $(\mathrm{t}=0 \mathrm{~h})$ remaining 354 after incubation $(\mathrm{t}=2 \mathrm{~h})$. 
355 Table 1: Choline chloride-based DESs in this study with their components and mole ratios.

\begin{tabular}{lll}
\hline DES & Component & Mole ratio \\
\hline ChCl:Gly & ChCl: glycerol & $1: 1$ \\
ChCl:U & ChCl: urea & $1: 2$ \\
ChCl:Glu & ChCl: glucose: water & $1: 1: 0.75$
\end{tabular}

356 ChCl: Choline chloride

357

358 


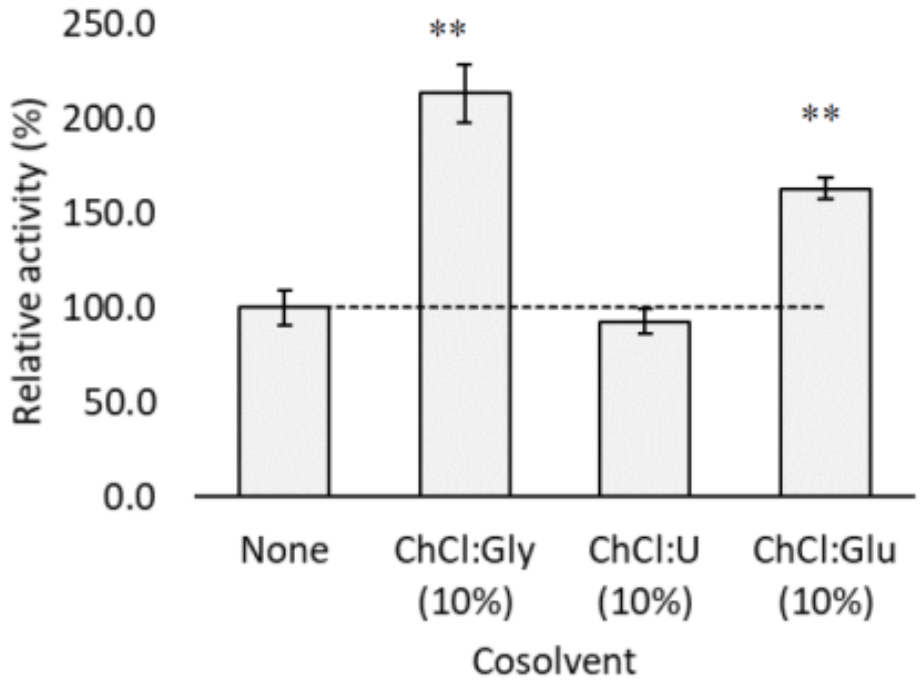

371

372 Figure 1: Effect of DES on the activity of AmCut. The enzyme was assayed at $37^{\circ} \mathrm{C}$ in $50 \mathrm{mM}$ phosphate buffer 373 pH7.5. Relative activity (\%) was determined by setting the activity of AmCut in buffer as the $100 \%$ reference.

374 All percentages refer to v/v. Note: ChClGlu was highly viscous and diluted with $27 \% \mathrm{v} / \mathrm{v}$ water to allow for ease 375 of handling (see Table 1). All percentages refer to $\mathrm{v} / \mathrm{v}$. 


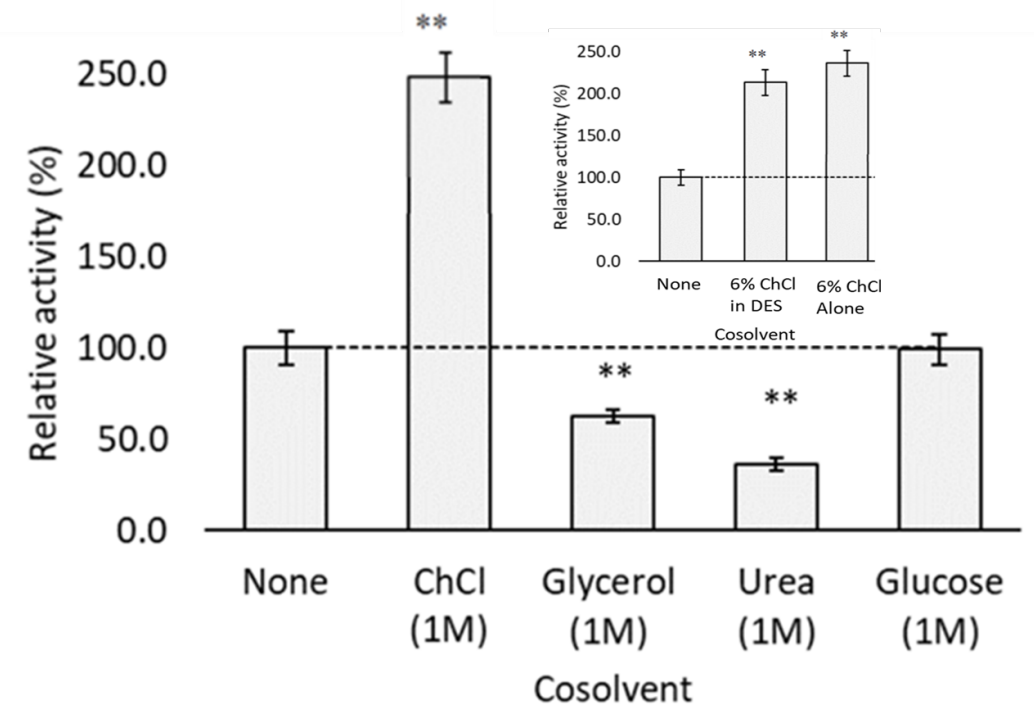

378

379 Figure 2: Effect of DES components on AmCut activity. AmCut was assayed at $37^{\circ} \mathrm{C}$ in $50 \mathrm{mM}$ phosphate

380 buffer $\mathrm{pH}$ 7.5. Relative activity (\%) was determined by setting the activity of AmCut in buffer as the $100 \%$

381 reference. The inset shows a direct comparison of $\mathrm{ChCl}$ as a component of DES (ChCl:Gly) at a level of $6 \%$

382 versus $\mathrm{ChCl}$ alone at $6 \%(\mathrm{w} / \mathrm{v})$. 


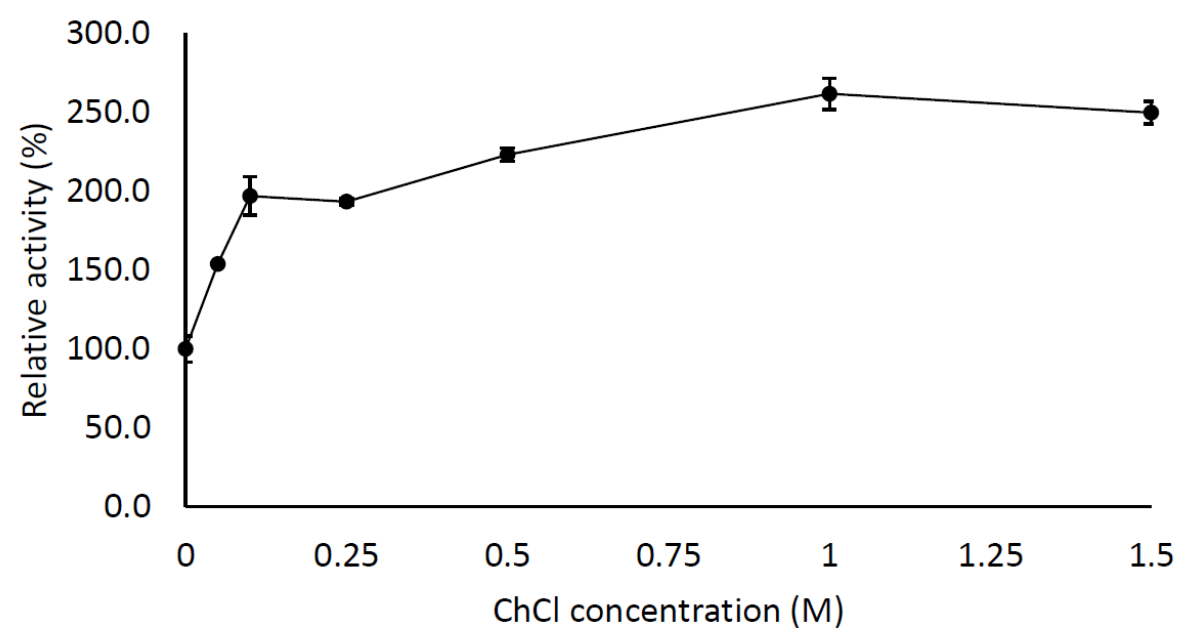

386

387 Figure 3: Effect of Choline Chloride $(\mathrm{ChCl})$ concentration on the activity of AmCut. The enzyme was assayed using the standard $p$ NPP assay in the presence of 0 to $1.5 \mathrm{M}$ of choline chloride at $37^{\circ} \mathrm{C}$ in $50 \mathrm{mM}$ sodium phosphate buffer, $\mathrm{pH}$ 7.5. Relative activity was determined using the activity of AmCut in buffer as the $100 \%$

390 reference.

391

392

393

394

395

396

397

398

399

400

401 


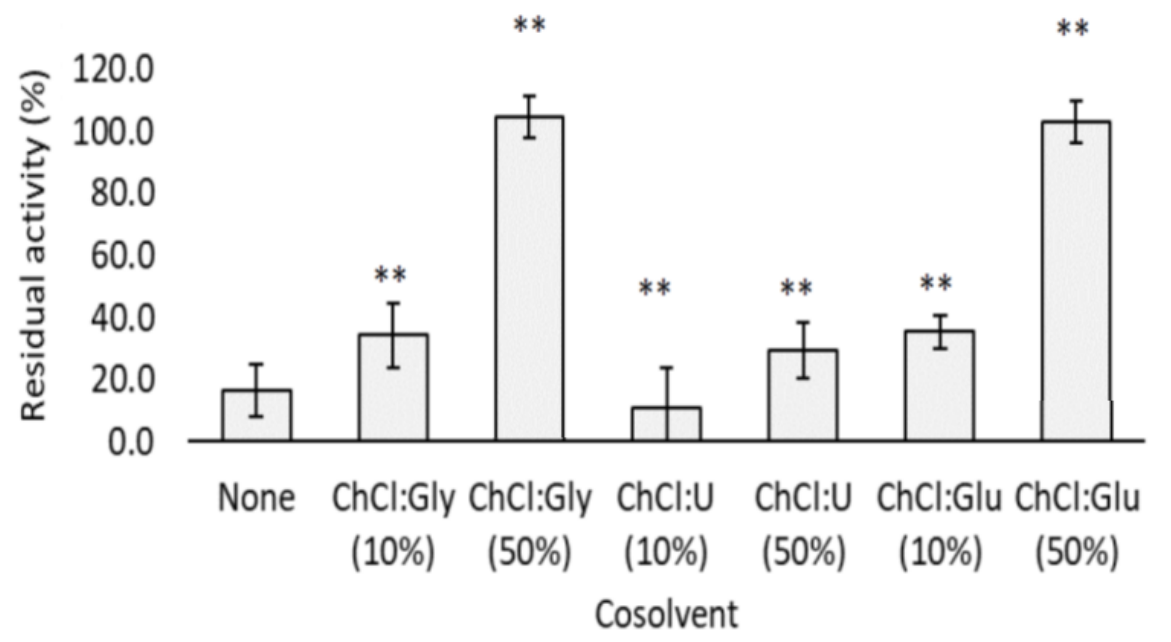

402

403 Figure 4: Effect of DESs on the stability of AmCut at $50^{\circ} \mathrm{C}$. The enzyme was incubated in phosphate buffer $\mathrm{pH}$

4047.5 containing appropriate DESs at $50^{\circ} \mathrm{C}$ for $2 \mathrm{hrs}$ and then assayed using the standard assay at $37^{\circ} \mathrm{C}$ in $\mathrm{pH} 7.5$.

405 The relative activity was calculated using the percentage of initial activity $(\mathrm{t}=0 \mathrm{~h})$ of the sample and after the

406 incubation $(\mathrm{t}=2 \mathrm{~h})$. Note: ChClGlu was highly viscous and diluted with $27 \% \mathrm{v} / \mathrm{v}$ water to allow for ease of

407 handling (see Table 1). All percentages refer to $\mathrm{v} / \mathrm{v}$.

408 


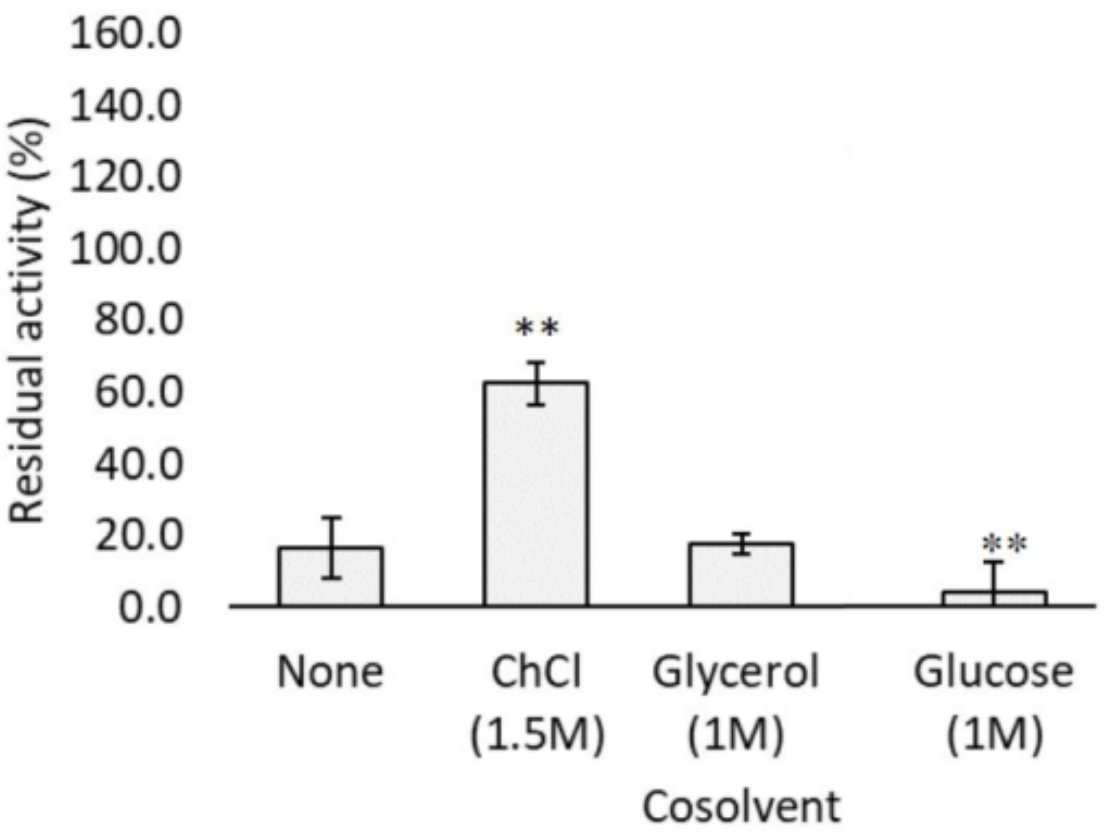

409

Figure 5: Effect of individual component of DES on AmCut activity at $50^{\circ} \mathrm{C}$. The enzyme was incubated in

411 phosphate buffer (pH7.5) in the presence of DES components for $2 \mathrm{hrs}$ and assayed using the standard assay at $41237^{\circ} \mathrm{C}$. Relative activity was the percentage of initial activity $(\mathrm{t}=0 \mathrm{~h})$ remaining after incubation $(\mathrm{t}=2 \mathrm{~h})$. 